\title{
The predatory mite Neoseiulus paspalivorus (Phytoseiidae) in Brazil: taxonomic status, reproductive compatibility and morphological and molecular variability
}

\author{
Daniela Rezende ${ }^{1} \cdot$ Denise Navia $^{2} \cdot$ Renata S. Mendonça $^{2}$. \\ José W. S. Melo ${ }^{3}$ Manoel G. C. Gondim Jr. ${ }^{1}$
}

Received: 12 May 2015/ Accepted: 6 October 2015

(C) Springer International Publishing Switzerland 2015

\begin{abstract}
The predatory mite Neoseiulus paspalivorus (De Leon) is often found in association with the coconut mite, Aceria guerreronis Keifer. The identification of natural enemies is essential for the definition of biological control strategies. Therefore, the present study aimed to confirm whether the mite populations from different Northeastern Brazilian states identified as $N$. paspalivorus belong to the same species. This determination was accomplished through the study of morphometric variability in 33 anatomical characters and of molecular variability in two DNA fragments: Internal Transcribed Spacer (ITS) rDNA and cytochrome c oxidase subunit I (COI) mtDNA. This study also determined whether there is reproductive isolation between the two most morphologically distinct populations (Rio Grande do Norte and Paraíba). Intraspecific morphometric variability was observed among the five populations of $N$. paspalivorus. Despite this variability, the crosses and backcrosses of the most morphologically distinct populations did not show reproductive incompatibility. The molecular analysis indicated the absence of genetic differences among the N. paspalivorus populations for the ITS fragment. Three haplotypes were identified for the COI fragment, and the genetic distance ranged from 0 to $0.2 \%$. Despite the morphometric differences, the results of the molecular and biological analysis corroborate the previous identification of $N$. paspalivorus for all of the studied populations. The present study contributes to the systematics of Phytoseiidae predatory mites and to the biological control of $A$. guerreronis by the accurate identification and characterization of one of its main natural enemies along extensive areas in Brazil.
\end{abstract}

Daniela Rezende

daniagroufv@hotmail.com

1 Programa de Pós-Graduação em Entomologia Agrícola, Departamento de Agronomia/Entomologia, Universidade Federal Rural de Pernambuco, Rua Dom Manoel de Medeiros s/n, Dois Irmãos, Recife, PE 52171-900, Brazil

2 Embrapa Recursos Genéticos e Biotecnologia, Parque Estação Biológica, final Av. W5 Norte, s/No., Asa Norte, Caixa Postal 02372, Brasília, DF 70770-900, Brazil

3 Departamento de Fitotecnia - Entomologia, Universidade Federal do Ceará, Avenida Mister Hull, n 2977, Bloco 805, Campus do Pici, Fortaleza, CE 60356-000, Brazil 
Keywords Aceria guerreronis · Biological control · Cocos nucifera · Genetic variability · Morphometry $\cdot$ Integrative taxonomy

\section{Introduction}

The coconut mite, Aceria guerreronis Keifer (Eriophyidae), is one of the most important arthropod pests of coconut in the world (Moore and Howard 1996; Navia et al. 2013). Several studies aimed at finding predatory mites that could be used in the management of A. guerreronis populations have been conducted in Africa (Negloh et al. 2008, 2010), America (Lawson-Balagbo et al. 2008; Reis et al. 2008; Silva et al. 2010) and Asia (Haq 2001; Ramaraju et al. 2002; de Moraes et al. 2004; Fernando and Aratchige 2010).

Aceria guerreronis develops on the fruit perianth (Moore and Howard 1996; Nair 2002; Lawson-Balagbo et al. 2007; Navia et al. 2013), which is the space between the coconut fruit surface and the set of bracts that links the fruit to the spikelet. The distance between the distal end of the bracts and the fruit surface is large enough for A. guerreronis penetration into the perianth but not large enough for the access of other mites (LawsonBalagbo et al. 2007; Lima et al. 2012), including most of the predatory mites. Neoseiulus paspalivorus (De Leon) and N. baraki (Athias-Henriot) (Phytoseiidae) are the species that stand out among the predatory mites frequently found in association with A. guerreronis in the perianth of coconut fruit in Brazil (Lawson-Balagbo et al. 2008; Lima et al. 2012; Reis et al. 2008), Africa (Negloh et al. 2008, 2010) and Asia (de Moraes et al. 2004). These Neoseiulus species have reduced size, a short legs and mainly flattened body (Chant and McMurtry 2003; de Moraes et al. 2004) when compared with other predatory mite species that are also found in association with A. guerreronis, such as Proctolaelaps bickleyi (Bram), P. bulbosus Moraes, Reis and Gondim Jr. (Melicharidae), and the phytoseiids Amblyseius largoensis (Muma) and Euseius alatus De Leon, which are larger body size (Lima et al. 2012; Melo et al. 2015). Those characteristics make N. paspalivorus and $N$. baraki the most promising species as biological control agents of A. guerreronis (Lima et al. 2012; Melo et al. 2015).

The phytoseiid $N$. paspalivorus was first described in a grass species of the genus Paspalum in Florida, USA, in 1956 (De Leon 1957). Later, this mite was reported in Asia (Ghai and Gupta 1984; Schicha and Corpuz-Raros 1992; de Moraes et al. 2004), Africa (Negloh et al. 2010; Famah Sourassou et al. 2011) and in America (Denmark and Muma 1978; de Moraes et al. 2000; Lawson-Balagbo et al. 2008; Reis et al. 2008), always in association with A. guerreronis in the perianth of coconut fruit. Neoseiulus paspalivorus was reported in Pluchea symphytifolia (Miller) (Asteraceae) in Guadeloupe (de Moraes et al. 2000). Neoseiulus paspalivorus is widely distributed in Brazil, and this mite has been observed in the states of Alagoas, Bahia, Ceará, Maranhão, Pará, Paraíba, Pernambuco, Piauí, Rio Grande do Norte and Sergipe (Lawson-Balagbo et al. 2008; Reis et al. 2008). In this country, $N$. paspalivorus occurs predominantly in areas characterised by long periods of drought, average temperatures ranging from 27 to $30{ }^{\circ} \mathrm{C}$, a relative humidity between 70 and $80 \%$ and an annual rainfall of $600-1500 \mathrm{~mm}$ (LawsonBalagbo et al. 2008).

The accurate identification of natural enemies is essential for biological control. The phytoseiid mites are currently identified based on morphological traits (e.g., Chant and McMurtry 1994, 2006). However it may be limiting for certain taxa. Cryptic species of 
Phytoseiidae have been reported in the literature (Tixier et al. 2006a), including species in the genus Neoseiulus (Famah Sourassou et al. 2012). Furthermore differences in biological characteristics and predation efficiency have been reported in geographically and genetically distinct populations (de Moraes and McMurtry 1985; Yaninek et al. 1993; Tixier et al. 2006a, b, 2010; Ferrero et al. 2007; Furtado et al. 2007; Okassa et al. 2011; Domingos et al. 2013).

The use of an integrated approach, combining molecular data, crossings experiments and morphological studies, has assisted the identification of Phytoseiidae species and provided knowledge concerning differences between populations. The integration of this information in taxonomic studies has contributed to advances in the systematics of predatory phytoseiid mites, supporting establishment of synonimies, revealing occurrence of cryptic species or characterizing genetic lineages (e.g., Tixier et al. 2008a; Okassa et al. 2009, 2011; Famah Sourassou et al. 2012; Navia et al. 2014).

Some studies with phytoseiidae mites in the genus Neoseiulus associated with the coconut mite have already been conducted. Famah Sourassou et al. (2011) performed multivariate morphometric analysis and crossing experiments with three populations of $N$. paspalivorus (Benin, Ghana and Brazil) and concluded that the studied populations were different species, despite their morphological similarity. Famah Sourassou et al. (2012) used multivariate morphometric analysis, molecular analyses and crossing experiments with populations of $N$. baraki from Benin, Tanzania and Brazil. The results also provided evidence for the existence of cryptic species.

Considering that cryptic species or reproductive isolation have already been detected among N. paspalivorus populations from other countries/continents (Famah Sourassou et al. 2011); that $N$. paspalivorus populations in Brazil occurs in geographically distant areas (Lawson-Balagbo et al. 2008) and could present reproductive isolation; and that genetic differences can be related with predatory behaviour and bioecological aspects (Famah Sourassou et al. 2011), it would be important to confirming that the mite populations identified as $N$. paspalivorus from different Brazilian states belong to the same taxon; that there is no reproductive isolation between the most morphologically distinct populations; and know if there is genetic variability among the populations. For these purposes, an integrative approach was used, combining three methods: morphometrics, DNA sequences analysis, and crossing experiments.

\section{Materials and methods}

\section{Sampling, identification, rearing and preservation of mites for analysis}

Coconut fruits with damage caused by A. guerreronis were collected in all nine states of northeast Brazil (Alagoas, Bahia, Ceará, Maranhão, Paraíba, Pernambuco, Piauí, Rio Grande do Norte and Sergipe), covering an area of approximately $3000 \mathrm{~km}$ along the Atlantic coast. Approximately ten coconut palms were sampled at each location. In each state one sample was collected, except for Rio Grande do Norte e Ceará, where samples were collected in two and three localities, respectively, in a way to obtain enough number of specimens to conduct experiments. The geographical coordinates of each sampling location were obtained with the aid of a global positioning system $\left(\right.$ GPSMAP $^{\circledR} 60 \mathrm{CSx}$, Garmin, Romsey, UK). 
The collected fruits were placed in plastic bags and stored in Styrofoam boxes for less than 2 days until transportation to the laboratory where they were stored in a refrigerator at approximately $10{ }^{\circ} \mathrm{C}$ for a maximum of 7 days until inspection. The phytoseiid mites were collected with a brush under a stereoscopic microscope. Approximately ten female from each sampling location were mounted on microscope slides in Hoyer's medium. The slides were placed in a drying chamber $\left( \pm 60^{\circ} \mathrm{C}\right)$ for 5 days and then observed under an Olympus optical microscope (model BX41, Olympus, Tokyo, Japan). The mites were identified using Phytoseiidae taxonomic studies (Chant and McMurtry 2003; de Moraes et al. 2004) and the original description of $N$. paspalivorus (De Leon 1957). When N. paspalivorus mites were found, all the fruits of the sample were inspected making possible collecting a higher number of specimens to establishing colonies and conduct experiments. Neoseiulus paspalivorus mites were found in five of the nine states in northeast Brazil where samples were collected: Ceará (CE), Paraíba (PB), Piauí (PI), Rio Grande do Norte (RN) and Sergipe (SE) (Fig. 1).

For each State in which $N$. paspalivorus mites were found, a colony was established with approximately 100 specimens, which were kept isolated in climatic chambers $\left(25 \pm 1{ }^{\circ} \mathrm{C}, 70 \pm 10 \%\right.$ relative humidity and a daily $12 \mathrm{~h}$ photophase). The rearing unit consisted of a black polypropylene disk ( $1 \mathrm{~mm}$ thick), filter paper, polyethylene foam $(1 \mathrm{~cm}$ thick) and a Petri dish, all superposed in this sequence and $16 \mathrm{~cm}$ in diameter. To prevent mites from escaping, the polypropylene disk was wrapped with hydrophobic cotton wool, which was kept constantly moist by daily addition of distilled water. Five fragments (approximately $1 \mathrm{~cm}^{3}$ ) of the epidermis of coconut fruit perianth infested with A. guerreronis (field collected) were supplied daily as food for the predatory mites (each fragment had approximately 80-100 specimens of different developmental stages).

One month after the colonies were established, 25 females were recovered from each colony for the morphometric analysis. Females were removed and mounted on microscope slides in Hoyer's medium. In addition fifteen females were removed, placed in absolute ethyl alcohol and subsequently kept at $-20{ }^{\circ} \mathrm{C}$ for the molecular analysis.
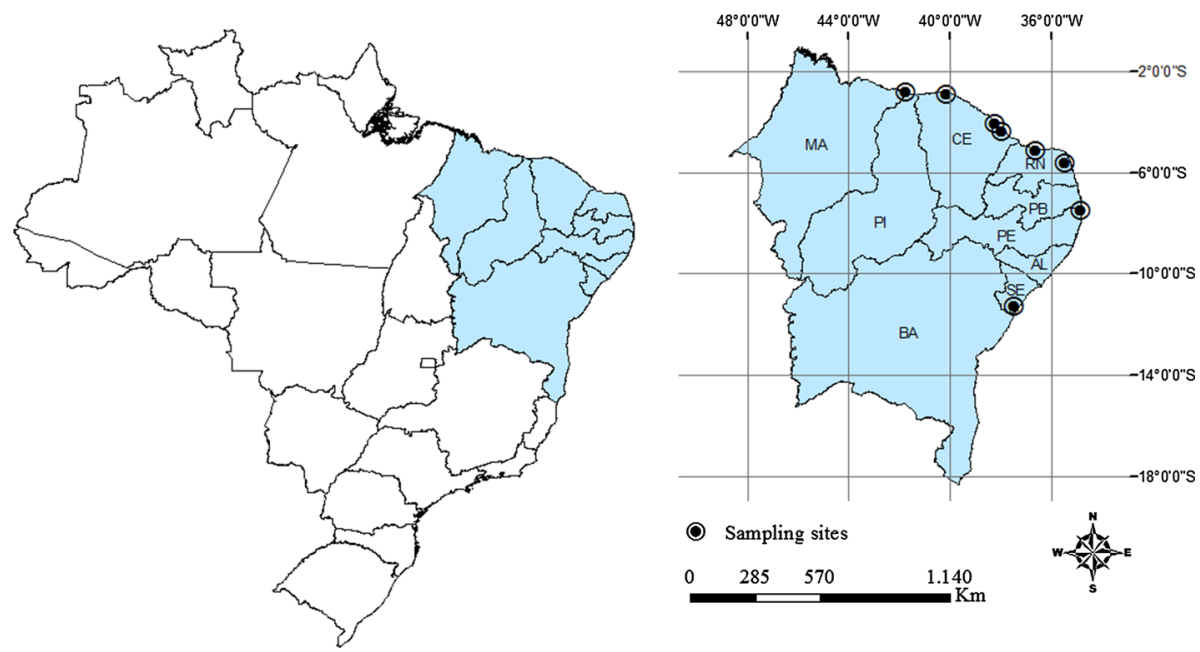

Fig. 1 Sampling locations of Neoseiulus paspalivorus populations in northeastern Brazil 


\section{Morphometric characterisation}

The morphometric analyses were performed with specimens collected from each of the five colonies-CE, RN, PB, PI and SE States, from now considered as a "population". Twenty females of each population were measured. The measurements were performed under an optical microscope $(400 \times$ magnification) coupled to a computer for image capturing using Honestech TVR 2.5 software. Thirty-three characters that are commonly used in the identification of phytoseiid mites (e.g., Chant and McMurtry 1994, 2003, 2006) were measured (see the list of characters in Table 1). The measurements were performed with Motic Images Plus 2.0 software. The nomenclature used in the present study follows Lindquist and Evans (1965), and the measurements are given in micrometres. The measurement data were subjected to one-way analysis of variance (PROC ANOVA) followed by the Student-Newman-Keuls (SNK) test $(\alpha=0.05)$. To estimate the overlap of characters among the populations, the following equation was used: $\Delta \mathrm{x}=\operatorname{Minx}-\mathrm{Maxx}$, where Minx is the lowest measurement for character " $x$ " in the population that had the highest mean value, and Maxx is the highest measurement for character " $x$ " in the population that had the lowest mean value (Tixier 2012). Multivariate analyses were also conducted, with an initial discriminant analysis performed to evaluate the re-identification of specimens based on variations in each population. Then, a canonical variable analysis (CVA) was performed to determine the morphological variation patterns and to identify the morphological characters that contribute most heavily to the morphological differentiation between populations. All of the statistical analyses were performed with SAS software (SAS Institute 2002). Measurements of studied populations were also compared with holotype measurements presented by De Leon (1957) in the species original description.

The mites measured for morphometric analysis were deposited as voucher specimens in the mite collection of the Laboratory of Acarology of the Universidade Federal Rural de Pernambuco (UFRPE), located in Recife, state of Pernambuco, Brazil, and also in the mite collection of the Empresa Brasileira de Pesquisa Agropecuária-Embrapa Recursos Genéticos e Biotecnologia, located in Brasília, Distrito Federal, Brazil.

\section{Crosses}

Reproductive compatibility tests were conducted with the $N$. paspalivorus populations from $\mathrm{PB}$ and $\mathrm{RN}$, which were the most morphometrically distant according to the CVA. Approximately 100 females of each population were transferred to new rearing units. After $24 \mathrm{~h}$, the females were removed, and the eggs were kept in the rearing units to obtain specimens of the same age. The specimens were fed in a manner similar to that previously described for the maintenance colonies. After 5 days, the resulting female deutonymphs were separated in experimental units consisting of a plastic container $(\varnothing=2 \mathrm{~cm} \times \mathrm{H}=1.8 \mathrm{~cm}),(128$-well bioassay tray, Bio-Serv, Frenchtown, NJ, USA). To prevent mites from escaping, the cells were sealed with a transparent, adhesive, plastic film. From each population studied, ten unmated females were kept in isolation for 10 days to determine whether unmated females would lay eggs. At the same time, ten homogamic

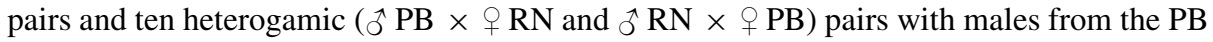
and $\mathrm{RN}$ colonies were formed. Any male that died during the oviposition period (10 days) was replaced by another male from the same original colony. Females resulting from the heterogamic crosses were backcrossed with males of the original populations (PB or RN). The pairs were evaluated for 10 days after the beginning of oviposition. Pre-oviposition 


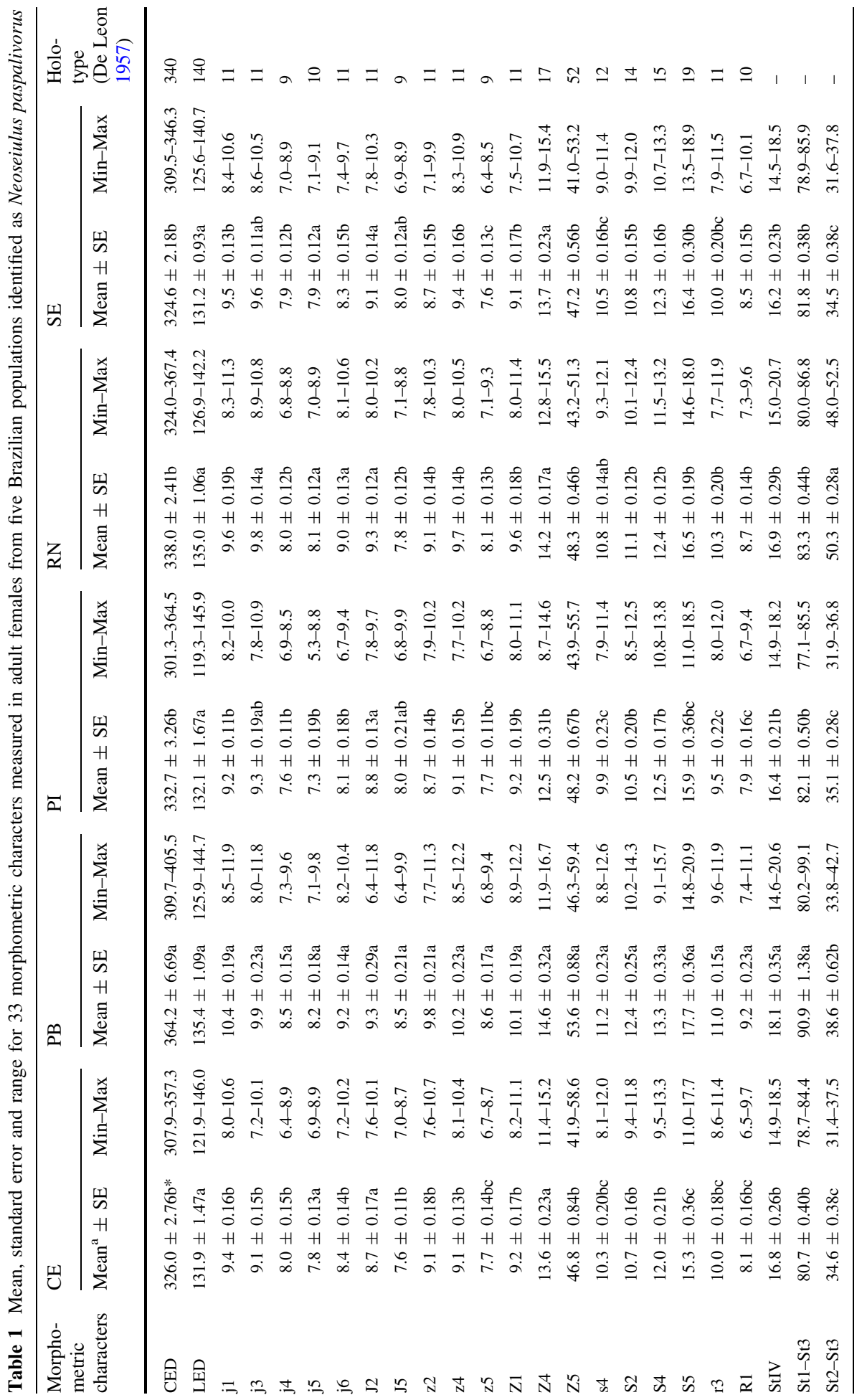




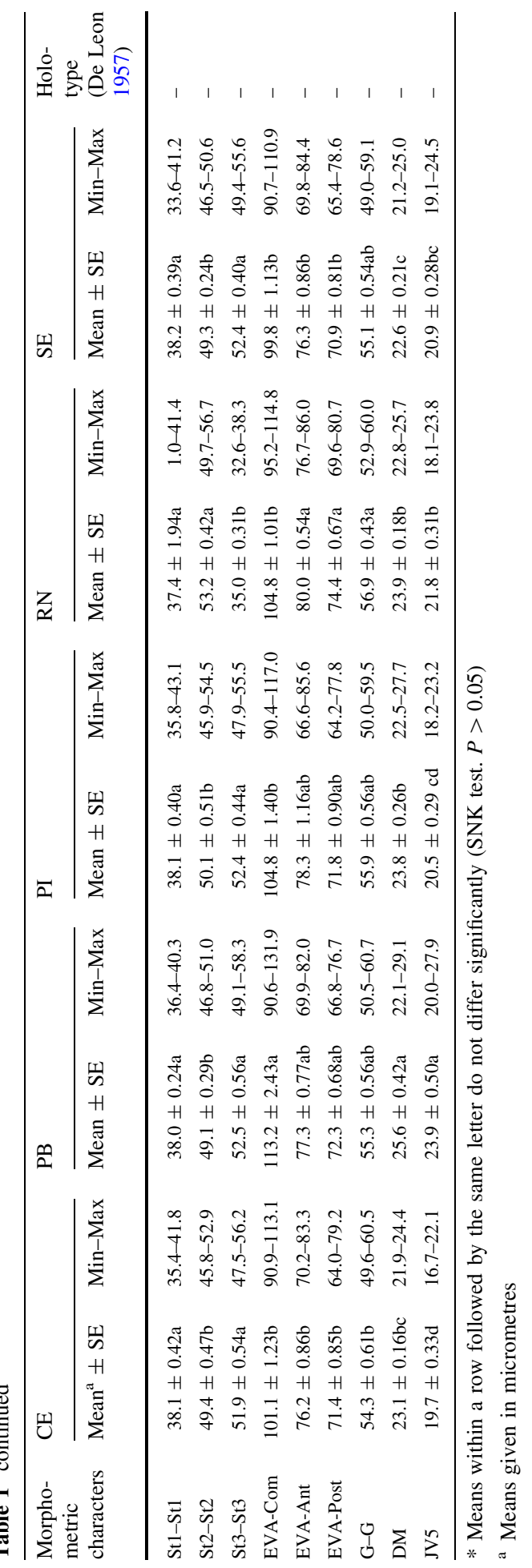


period, number of eggs per female, total egg viability and sex ratio were evaluated in the homogamic and heterogamic crosses. To evaluate the sex ratio, the pairs were transferred every 3 days to new experimental units, and the eggs were kept in the same units to obtain adults, which were then sexed. A fragment (approximately $1 \mathrm{~cm}^{3}$ ) of epidermis of the perianth of field collected coconut fruit infested with A. guerreronis (approximately 80-100 specimens of different developmental stages) was supplied daily as food. The experimental units were kept in climatic chambers at $25 \pm 1{ }^{\circ} \mathrm{C}, 75 \pm 10 \%$ relative humidity and a daily 12-h photophase. The differences between the treatments (crosses and backcrosses) for pre-oviposition period, number of eggs per female, viability and sex ratio were evaluated by analysis of variance (PROC ANOVA) followed by the SNK test $(\alpha=0.05)$ using SAS software (SAS Institute 2002).

\section{Molecular characterisation}

Two fragments of the genome of five $N$. paspalivorus populations (CE, PB, PI, RN and SE) were sequenced: the intergenic region internal transcribed spacer (ITS), covering the ITS1 and ITS2 regions and the 5.8S gene (ITS1-5.8S-ITS2) of the nuclear ribosomal genome (rDNA), and a fragment of the cytochrome c oxidase subunit I (COI) of the mitochondrial genome (mtDNA). These fragments were chosen for the present study because these markers are independent and complementary, with a distinct evolutionary rate. The ITS region has been used in studies of the Phytoseiidae family to elucidate important aspects related to phylogeny (Kanouh et al. 2010a; Tsolakis et al. 2012) and confirm taxonomic status (e.g., Gotoh et al. 1998; Hillis and Dixon 1991; Navajas and Fenton 2000; Navajas et al. 1999) as well as to clarify synonyms and verify the occurrence of cryptic species (Tixier et al. 2006a, 2011, 2012; Navia et al. 2014). The COI region has been used in the confirmation of phytoseiid species (Tixier et al. 2008a; Okassa et al. 2009); the clarification of taxonomic problems, such as synonyms (Tixier et al. 2006a, b, 2011); and the detection of cryptic species of the genus Neoseiulus (i.e. Famah Sourassou et al. 2012).

\section{DNA extraction}

Fifteen $N$. paspalivorus females of each population were isolated for genomic DNA extraction, which was performed separately for each specimen using a "DNeasy Blood and Tissue Kit" (Qiagen ${ }^{\circledR}$, USA). The extraction followed the protocol for animal cell culture, which was adapted for the extraction of total DNA from small arthropods, as described by Mendonça et al. (2011), with the adjustments proposed by Kanouh et al. (2010b). The specimens used for the DNA extractions, whenever possible, had their exoskeleton recovered from the membrane of the extraction column and mounted on microscope slides in Hoyer's medium (Tixier et al. 2010). These slides were deposited as voucher specimens in the mite collection of Embrapa Genetic Resources and Biotechnology, Brasília, Distrito Federal, Brazil.

\section{DNA amplification}

The primers used for PCR amplification of the ITS region were 5'-AGAGGAAG TAAAAGTCGTAACAAG-3' (Navajas et al. 1999) and 5'-ATATGCTTAAATT CAGCGGG-3' (Navajas et al. 1998). The COI fragment was amplified with primers 5'TGATTTTTTGGTCACCCAGAAG and 5'-TACAGCTCCTATAGATAAAAC (Navajas et al. 1996). 
The PCR reaction used for the ITS amplification was adapted from the protocol proposed by Navia et al. (2014). The reaction had a final volume of $25 \mu \mathrm{L}$, containing $2.5 \mu \mathrm{L}$ of 10X buffer (Qiagen $\left.{ }^{\circledR}\right), 0.125 \mathrm{un} / \mu \mathrm{L}(5 \mathrm{U} / \mathrm{mL})$ Taq DNA polymerase (Qiagen $\left.{ }^{\circledR}\right), 0.5 \mu \mathrm{L}$ of dNTP $(10 \mathrm{mM}), 0.175 \mu \mathrm{L}$ of each primer $(10 \mu \mathrm{M}), 1 \mu \mathrm{l}$ of $\mathrm{MgCl}_{2}(25 \mathrm{mM}), 18.525 \mu \mathrm{L}$ of MiliQ water and $2 \mu \mathrm{L}$ of DNA. The thermocycler (Eppendorf Mastercycler pro S) was set with the following program: denaturation at $94{ }^{\circ} \mathrm{C}$ for 2 min followed by 30 cycles of $94{ }^{\circ} \mathrm{C}$ for $15 \mathrm{~s}$ (denaturation), $51{ }^{\circ} \mathrm{C}$ for $45 \mathrm{~s}$ (annealing) and $72{ }^{\circ} \mathrm{C}$ for $1 \mathrm{~min}$ (extension), ending with one cycle of $72{ }^{\circ} \mathrm{C}$ for $7 \mathrm{~min}$, dropping to $10{ }^{\circ} \mathrm{C}$ until the samples were removed.

The COI region was amplified following the protocol proposed by Famah Sourassou et al. (2012). The final reaction volume was $25 \mu \mathrm{L}$, containing $2.5 \mu \mathrm{L}$ of $10 \mathrm{X}$ buffer $\left(\right.$ Qiagen $\left.{ }^{\circledR}\right), 0.5 \mathrm{un} / \mu \mathrm{L}(5 \mathrm{U} / \mathrm{mL})$ Taq DNA polymerase (Qiagen $\left.{ }^{\circledR}\right), 2 \mu \mathrm{L}$ of dNTP $(10 \mathrm{mM})$, $0.5 \mu \mathrm{L}$ of each primer $(10 \mu \mathrm{M}), 1 \mu \mathrm{l}$ of $\mathrm{MgCl}_{2}(25 \mathrm{mM}), 0.4 \mu \mathrm{L}$ of BSA, $15.6 \mu \mathrm{L}$ of DEPC water and $2 \mu \mathrm{L}$ of DNA. The thermocycler (Eppendorf Mastercycler pro $\mathrm{S}$ ) was set with the following program: denaturation at $95{ }^{\circ} \mathrm{C}$ for $2 \mathrm{~min}, 30$ cycles of $92{ }^{\circ} \mathrm{C}$ for $2 \mathrm{~min}$ (denaturation), $45^{\circ} \mathrm{C}$ for $1 \mathrm{~min}$ (annealing) and $72{ }^{\circ} \mathrm{C}$ for $90 \mathrm{~s}$ (extension), ending with a final cycle of $72{ }^{\circ} \mathrm{C}$ for $5 \mathrm{~min}$, dropping to $10{ }^{\circ} \mathrm{C}$ until the samples were removed.

The amplified PCR products were subjected to electrophoresis in $1 \%$ agarose gel stained with GelRed ${ }^{\circledR}$ (Biotium) and visualised in a transilluminator (BioRad) coupled to a computer with Image Lab 3.0 software.

Four to six specimens from each population were sequenced for both target fragments. The COI and ITS sequences were sequenced from the same mite individuals. Not every DNA template was sequenced for COI fragment because of problems in obtaining PCR amplification, probably resulting from the degraded state of some specimens. Therefore, the COI data set was reduced. The PCR product was sent for direct sequencing on an ABI PRISM 3730xl platform (Applied Biosystems, Lille, France).

\section{Sequence analysis}

The ITS (rDNA) and COI (mtDNA) sequences were aligned according to the multiple alignment method CLUSTALW (Thompson et al. 1994) using BioEdit software. No manual adjustments were necessary to align the sequences. The distribution and frequency of the variant sequences - the haplotypes (COI) and genotypes (ITS) - for the N. paspalivorus specimens were inferred for the two fragments under study and estimated in DnaSP version 5.10.1 software (Librado and Rozas 2009).

\section{Results}

\section{Morphometric characterisation}

Significant differences were observed among the five $N$. paspalivorus populations for most of the characters measured $(P<0.05)$ (Table 1$)$, except the width of the dorsal shield (WDS), the length of the $\mathrm{J} 2$ setae and the distance between sternal setae St1-St1. An overlap of the variation ranges was observed for most of the characters studied, with the exception of the distance between sternal setae (St3-St3) of the population collected in RN and the other populations studied. 
Table 2 Identification based on discriminant analysis of 33 morphological characters in females from five geographic populations of Neoseiulus paspalivorus

\begin{tabular}{lcrrrrr}
\hline State & \% Well-classified $^{\text {a }}$ & CE & PB & PI & RN & SE \\
\hline CE & 50 & 10 & 2 & 6 & 0 & 2 \\
PB & 65 & 3 & 13 & 1 & 0 & 3 \\
PI & 45 & 8 & 0 & 9 & 0 & 3 \\
RN & 100 & 0 & 0 & 0 & 20 & 0 \\
SE & 75 & 2 & 1 & 2 & 0 & 15 \\
Total & 67 & 23 & 16 & 18 & 20 & 23 \\
\hline
\end{tabular}

${ }^{a}$ Percentage of specimens in the population of origin that were well rated

In the discriminant analysis, the females of the $\mathrm{RN}$ population were well defined, showing $100 \%$ identity with their population of origin. For the other populations, the identity percentage ranged from 45 to $75 \%$, with the proportionately largest errors in identification observed in the populations from CE and PI (Table 2).

The first two canonical variables (CV1 and CV2) together explained $96.4 \%$ of the total variance (CV1, $90.5 \%$; CV2, $5.9 \%$ ) (Fig. 2). All of the specimens of the RN population were plotted along the positive section of the CV1 axis, whereas the remaining populations were plotted along the negative section of the same axis. Therefore, there was no overlap between the population from RN and the other studied populations, indicating the complete morphometric separation of the RN population (Fig. 2). CV2 segregated the PB population, which was plotted along the positive section of the CV2 axis, from the other studied populations, which were predominantly plotted along the negative section of the CV2 axis. Only slight overlap was observed between the population from PB and that from CE. There was considerable overlap between the populations from CE, PI and SE, indicating morphometric similarity among them (Fig. 2).

The analysis of the CV1 and CV2 weights (Table 3) indicated that the length of the dorsal setae and the distance between the sternal shield setae are the main characteristics that differentiate the $N$. paspalivorus populations. The $N$. paspalivorus population from RN differed from the other populations by presenting a greater distance between sternal setae St2-St2 and St2-St3, a greater width of the posterior part of the ventrianal shield (postVAS) and the shortest distance between sternal setae St3-St3. The N. paspalivorus population from PB differed from the other populations along CV2 because of the greater length of its dorsal setae J5, r3, S4, Z4, s5 and j5 and StIV macrosetae.

\section{Crosses}

The virgin females laid no eggs during the observation period. In the homogamic and heterogamic crosses and backcrosses between the populations from PB and RN, all the females laid eggs without malformation. There was no statistically significant difference among the homogamic and heterogamic crosses and the backcrosses for the following evaluated parameters: pre-oviposition period $\left(F_{7,71}=2.25 ; P=0.05\right)$, number of eggs per female $\left(F_{7,71}=1.82 ; P=0.09\right)$, total viability $\left(F_{7,71}=1.22 ; P=0.30\right)$ and sex ratio $\left(F_{7,71}=1.07 ; P=0.39\right)$ (Table 4$)$. 


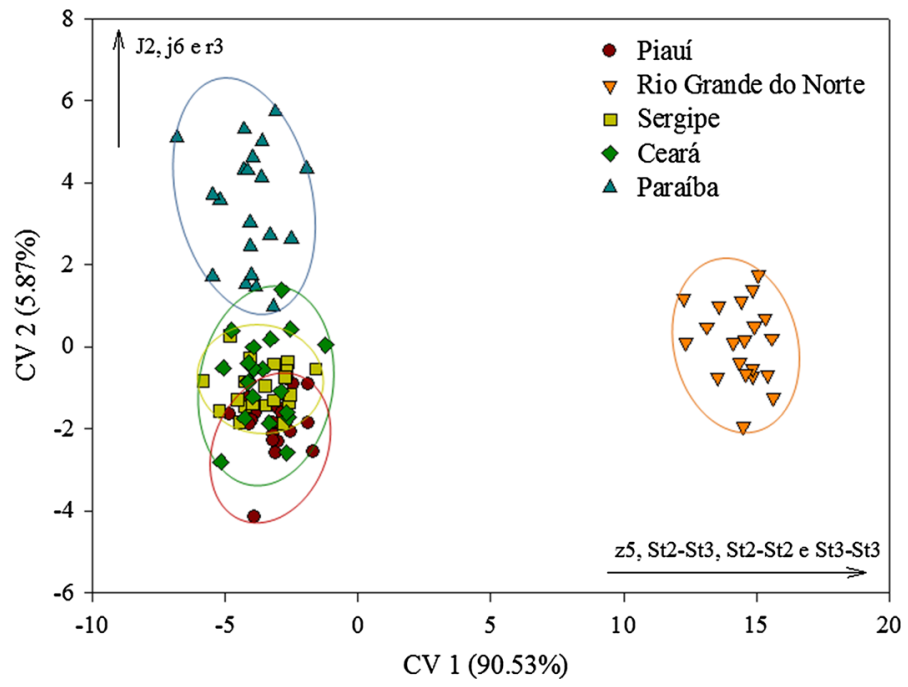

Fig. 2 Analysis of canonical variables for 33 morphological characters of females from five geographic populations of Neoseiulus paspalivorus, with the circles formed based on the projection of the specimens of each population for canonical variable (CV) 1 and 2 . The variation explained by the two canonical variables is shown in brackets

Table 3 Analysis of canonical variables for females of five Neoseiulus paspalivorus populations from northeastern Brazil showing the first ten morphometric characters (eigenvectors) with higher loadings (eigenvalues) for two canonical variables (CV1 and CV2) in decreasing order of absolute values

\begin{tabular}{lclc}
\hline Morphometric characters & CV1 (loadings) & Morphometric characters & CV2 (loadings) \\
\hline z5 & -0.5707 & J2 & -0.7396 \\
St2-St3 & 0.5052 & J5 & -0.4089 \\
St3-St3 & -0.4955 & j6 & 0.4076 \\
St2-St2 & 0.4909 & r3 & 0.4019 \\
j3 & 0.2641 & StIV & 0.3783 \\
R1 & 0.2628 & S4 & -0.3348 \\
j1 & -0.2534 & EVA-Post & -0.2921 \\
J5 & 0.2469 & z4 & 0.2681 \\
j6 & 0.2277 & $\mathrm{~s} 4$ & -0.2571 \\
EVA-Post & 0.2196 & j5 & 0.2546 \\
\hline
\end{tabular}

\section{Molecular characterisation}

Twenty-nine sequences were obtained within the ITS region for the $N$. paspalivorus specimens from the five states in the Brazilian Northeast (CE, PB, PI, RN and SE). The length of the fragments obtained ranged from 613 to $627 \mathrm{bp}$. All of the unpublished sequences were deposited in GenBank (accession number KP250646-KP250651 for CE, KP250629-KP250634 for PB, KP250635-KP250640 for PI, KP250641-KP250645 for RN and KP250623-KP250628 for SE). 


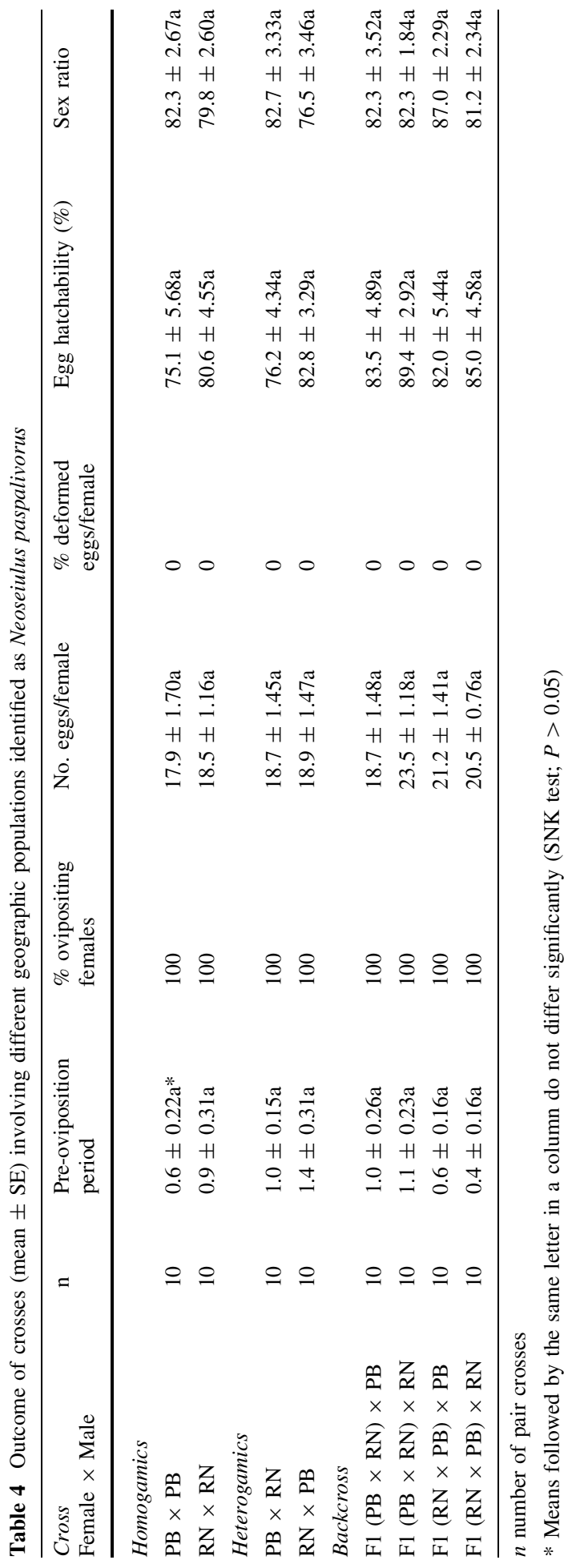


Table 5 Accession numbers and attributed haplotype codes of COI sequences of the predatory mite, Neoseiulus paspalivorus, obtained in this study

\begin{tabular}{lll}
\hline Haplotype number & GenBank accession number & States \\
\hline H1 & KR492517 & SE \\
& KR492518 & SE \\
& KR492519 & PB \\
& KR492520 & RN \\
& KR492521 & RN \\
& KR492522 & RN \\
& KR492523 & RN \\
& KR492524 & CE \\
H2 & KR492525 & CE \\
H3 & KR492526 & CE \\
\hline
\end{tabular}

No genetic variability was observed among $N$. paspalivorus populations. The average mean divergence within $N$. paspalivorus studied populations was $0.0 \%$ with a single genotype identified.

For the COI mitochondrial gene fragment, ten sequences representing the populations collected in CE, PB, RN and SE were obtained and deposited in GenBank (Table 5). The population from PI was not characterized for the ITS, since it was not possible to obtain good quality sequences of this region for their specimens. The COI fragment ranged from 390 to $450 \mathrm{bp}$ and corresponded to the 712 to $1102 \mathrm{bp}$ and the 712 to $1162 \mathrm{bp}$ positions, respectively, of the complete mitochondrial genome of the phytoseiid mite Phytoseiulus persimilis Athias-Henriot, available in GenBank (accession number NC014049). As observed for $N$. baraki (Famah Sourassou et al. 2012), the COI aligned sequences of $N$. pasplivorus were similar in nucleotide composition and $\mathrm{A}-\mathrm{T}$ rich $(27.03 \%$ Adenine; $45.71 \%$ Thymine). The translation of the nucleotide sequence resulted in a sequence with 146 amino acids.

Little polymorphism was observed among the ten COI sequences, and three haplotypes were identified $(\mathrm{H}=3)$. The genetic distance ranged from 0 to $0.2 \%$. $\mathrm{H} 1(\mathrm{n}=8)$ was present in the populations from $\mathrm{CE}, \mathrm{PB}, \mathrm{RN}$ and $\mathrm{SE}$. $\mathrm{H} 2$ and $\mathrm{H} 3$ were identified only in the population collected in $\mathrm{CE}$ (Table 5). $\mathrm{H} 2$ and $\mathrm{H} 3$ each showed a single nucleotide change, the replacement of $\mathrm{G}$ by A at position 305 of $\mathrm{H} 2(\mathrm{n}=1)$ and the replacement of $\mathrm{T}$ by $\mathrm{G}$ at position 180 of $\mathrm{H} 3(\mathrm{n}=1)$.

\section{Discussion}

Morphometric variability was observed among the $N$. paspalivorus populations under study, with a clear distinction of the population from RN. Intraspecific variability has been frequently reported in phytoseiid mites (e.g., Tixier et al. 2006a, b, 2008b). Misinterpretations of intraspecific variation can lead to misidentification and likely erroneous descriptions of new species (Tixier et al. 2008b). To minimise possible identification errors, Tixier (2012) proposed a statistical approach that establishes limits to distinguish between intra- and interspecific variability based on the length of phytoseiid setae. The Tixier (2012) study used 14 species of five genera (Euseius Wainstein, Neoseiulus Hughes, Phytoseiulus Evans, Kampimodromus Nesbitt and Typhlodromus (Typhlodromus) Scheuten). The minimum difference between the average values of samples belonging to two 
different species must be $10.58 \mu \mathrm{m}$ (for setae $<65 \mu \mathrm{m}$ ) and $33.99 \mu \mathrm{m}$ (for setae $>65 \mu \mathrm{m}$ ) (Tixier 2012). According to this approach, the variability found between the N. paspalivorus populations of the present study reflects intraspecific variability. However, in the present study, the seta length was not the characteristic that most influenced the morphometric distance of the populations.

The overlap of the character variation intervals indicates morphological similarity among the studied populations. The only morphometric character with no overlap of the variation ranges between the RN population and the other studied populations was the distance between the sternal setae St3-St3. Yet, this character has never been considered for distinguishing phytoseiid species (Chant and McMurtry 2003; de Moraes et al. 2004). The measurements of the $N$. paspalivorus populations under study were similar to the holotype (De Leon 1957) and other populations from Sri Lanka (de Moraes et al. 2004), Benin, Ghana and Brazil (Itamaracá, Pernambuco) (Famah Sourassou et al. 2011).

Several authors have reported morphometric differences between populations of phytoseiid species (e.g., Chant 1955; Ragusa and Tsolakis 1994; Tixier et al. 2006a, b, 2008a, b); however, little is known regarding the factors that can cause morpholoical variability. Studies have shown that arthropod populations may experience morphological variations along their geographical distribution (Saunders 1982). In eriophyid mites, cases of morphological variation have been associated with host specificity, and certain studies have shown that the involved characters very according to the structure of the host plant (Skoracka et al. 2002). Studies with Euseius mesembrinus (Dean), a mite of the Phytoseiidae family, attributed the morphological variations observed in populations from Florida and Texas (USA) to geographical or nutritional factors because the morphological variations were verified only in field specimens, whereas in the laboratory under conditions in which food resources and other ecological factors were controlled, the variations did not occur (Abou-Setta et al. 1991). Furtado (1997) hypothesised that food may affect the size of characters in Euseius citrifolius Denmark and Muma reared under laboratory conditions. However, there was no significant difference between females reared with different food supplies. In the present study, the population from $\mathrm{RN}$ was the most morphometrically distant of other five populations. This Brazilian state occupies an geographic intermediate position among the sampling locations; thus, it is likely that the variability found in the population from $\mathrm{RN}$ is unrelated to the geographical separation of the sampling sites. Regarding nutritional factors, reports of $N$. paspalivorus in Brazil are limited to its association with A. guerreronis on coconut palm, with little information concerning its ecology. However, it is most likely that $N$. paspalivorus has other still unknown prey and hosts whose occurrence along the northeast coast may not be continuous and uniform because the weather along the coast, especially the precipitation, is variable. Therefore, more research on $N$. paspalivorus is needed to elucidate its ecology and the factors associated with its morphometric variability.

The lack of oviposition in unmated females of $N$. paspalivorus confirms the need for sexual reproduction in this species (Famah Sourassou et al. 2011), as in most phytoseiids (Croft 1970; de Moraes and McMurtry 1981; Noronha and de Moraes 2002, 2004). The lack of reproductive isolation between the most morphometrically distant $N$. paspalivorus populations ( $\mathrm{RN}$ and $\mathrm{PB}$ ) supports the hypothesis that the studied populations belong to a single species, according to the biological concept of species (Mayr 1977). Previous studies have reported reproductive incompatibility among three geographically distant, N. paspalivorus populations (Benin, Ghana and Brazil) because of their association with different endosymbionts. The populations from Benin and Brazil carried different strains of Wolbachia, whereas the population from Ghana carried Cardinium (Famah Sourassou et al. 
2011, 2014). The absence of reproductive isolation observed in the present study, besides confirming the co-specificity of the populations, may be related to the absence of endosymbionts or the presence of the same endosymbiont species in all the populations. Therefore, as a future perspective, $N$. paspalivorus populations from the Brazilian Northeast populations should be screened for endosymbionts. This endosymbiont characterization may be useful concerning the coconut mite biological control since the introduction of populations with different strains of endosymbionts could cause reproductive incompatibility among Brazilian populations.

In addition to the reproductive compatibility observed in the present study, the molecular characterisation based on the ITS marker showed no genetic variability. For the COI marker, the genetic distance ranged from 0 to $0.2 \%$, which corresponds to intraspecific distances previously reported for populations of $N$. paspalivorus from Benin, Ghana and Brazil (Famah Sourassou et al. 2014). Despite the presence of two haplotypes in the population from $\mathrm{CE}$, suggesting greater genetic variability among the specimens of this population, these two polymorphic sites may represent a single, isolated event. The low genetic variability observed among the studied populations collected from geographically distant areas along the Brazilian coast suggests that $N$. paspalivorus is not a native species of Brazil location, since that the center of origin of a specie is defined as the geographic area wherein the specie exhibits the highest degree of variation (Gasparich et al. 1997). Phylogenetic and phylogeographic studies including populations from different localities/continents and hosts should be conducted to determine the centre of origin of $N$. paspalivorus.

Separately morphological analysis could leave doubts on the taxonomic unit of studied populations, taking into account the complete or almost complete morphometric discontinuity among populations. However, the molecular and biological (reproductive compatibility) analyses revealed no significant differences among the studied populations, corroborating to the prior identification of $N$. paspalivorus for all of the populations studied (CE, PB, PI, RN and SE). The present study highlights the importance of the precise identification of predatory mites through an integrative approach. Molecular characterization allowed obtaining the first DNA sequences of $N$. paspalivorus and its deposit in public databases making this information available for future studies on the molecular systematics of phytoseiid mites and also for predatory mites molecular diagnosis. Obtained results also contributed to the knowledge on Phytoseiidae systematics by providing information on the morphometric and genetic variability of $N$. paspalivorus populations from a continuous and extensive geographic area in Brazil.

Acknowledgments The authors would like to thank the Universidade Federal Rural de Pernambuco (UFRPE) and Embrapa Recursos Genéticos e Biotecnologia for logistic support. Thanks are also due for financial support to the Programa de Apoio a Planos de Reestruturação e Expansão das Universidades Federais (REUNI), and the Coordenação de Aperfeiçoamento de Pessoal de Nível Superior (CAPES), the Conselho Nacional de Desenvolvimento Científico e Tecnológico $(\mathrm{CNPq})$ and the Fundação de Amparo à Ciência e Tecnologia de Pernambuco (FACEPE).

\section{References}

Abou-Setta MM, Childers CC, Denmark HA, Browning HW (1991) Comparative morphology and reproductive compatibility between populations of Euseius mesembrinus (Acari: Phytoseiidae) from Florida and Texas. Exp Appl Acarol 10:213-220. doi:10.1007/BF01198651 
Chant DA (1955) Notes on mites of the genus Typhlodromus Scheuten, 1857 (Acarina: Laelaptidae), with descriptions of the male of some species and the female of a new species. Can Entomol 87:496-503. doi:10.4039/Ent87496-11

Chant DA, McMurtry JA (1994) A review of the subfamilies Phytoseiinae and Typholodrominae (Acari: Phytoseiidae). Int J Acarol 20:223-310

Chant DA, McMurtry JA (2003) A review of the subfamily Amblyseiinae Muma (Acari: Phytoseiidae). Part I. Neoseiulini new tribe. Int J Acarol 29:3-46. doi:10.1080/01647950308684319

Chant DA, McMurtry JA (2006) A review of the subfamily Amblyseiinae Muma (Acari: Phytoseiidae) Part IX. An overview. Int J Acarol 32:125-152. doi:10.1080/01647950608684453

Croft BA (1970) Comparative study on four strains of Typhlodromus occidentalis (Acarina: Phytoseiidae). I. Hybridization and reproductive isolation studies. Ann Entomol Soc Am 63:1559-1563. doi:10.1093/ aesa/63.6.1558

De Leon D (1957) Three new Typhlodromus from southern Florida (Acarina: Phtyoseiidae). Fla Entomol 40:141-144

de Moraes GJ, McMurtry JA (1981) Biology of Amblyseius citrifolius (Denmark and Muma) (AcarinaPhytoseiidae). Hilgardia 49:1-29

de Moraes GJ, McMurtry JA (1985) Comparison of Tetranychus evansi and T. urticae (Acari: Tetranychidae) as prey for eight species of phytoseiid mites. Entomophaga 30:393-397. doi:10.1007/ BF02372345

de Moraes GJ, Kreiter S, Lofego AC (2000) Plant mites (Acari) of the French Antilles. 3. Phytoseiidae (Gamasida). Acarologia 40:237-264

de Moraes GJ, Lopes PC, Fernando LCP (2004) Phytoseiid mites (Acari: Phytoseiidae) of coconut growing areas in Sri Lanka, with descriptions of three new species. J Acarol Soc Jpn 13:141-160. doi:10.2300/ acari.13.141

Denmark HA, Muma MH (1978) Phytoseiidae of Jamaica, an annotated list (Acari: Mesostigmata). Int J Acarol 4:1-22. doi:10.1080/01647957808683094

Domingos CA, Oliveira LO, Morais EGF, Navia D, de Moraes GJ, Gondim MGC Jr (2013) Comparison of two populations of the pantropical predator Amblyseius largoensis (Acari: Phytoseiidae) for biological control of Raoiella indica (Acari: Tenuipalpidae). Exp Appl Acarol 60:83-93. doi:10.1007/s10493012-9625-y

Famah Sourassou N, Hanna R, Zannou I, de Moraes GJ, Negloh K, Sabelis MW (2011) Morphological variation and reproductive incompatibility of three coconut-mite-associated populations of predatory mites identified as Neoseiulus paspalivorus (Acari: Phytoseiidae). Exp Appl Acarol 53:323-338. doi: $10.1007 / \mathrm{s} 10493-010-9413-5$

Famah Sourassou N, Hanna R, Zannou I, Breeuwer JAJ, de Moraes GJ, Sabelis MW (2012) Morphological, molecular and cross-breeding analysis of geographic populations of coconut-mite-associated predatory mites identified as Neoseiulus baraki: evidence for cryptic species? Exp Appl Acarol 57:15-36. doi:10. 1007/s10493-012-9534-0

Famah Sourassou N, Hanna R, Breeuwer JAJ, Negloh K, de Moraes GJ, Sabelis MW (2014) The endosymbionts Wolbachia and Cardinium and their effects in three populations of the predatory mite Neoseiulus paspalivorus. Exp Appl Acarol 64:207-221. doi:10.1007/s10493-014-9820-0

Fernando LCP, Aratchige NS (2010) Status of coconut mite Aceria guerreronis and biological control research in Sri Lanka. In: Sabelis MW, Bruin J (eds) Trends in acarology. Springer, Amsterdam, pp 379-384

Ferrero M, de Moraes GJ, Kreiter S, Tixier M-S, Knapp M (2007) Life tables of the predatory mite Phytoseiulus longipes feeding on Tetranychus evansi at four temperatures (Acari: Phytoseiidae, Tetranychidae). Exp Appl Acarol 41:45-53. doi:10.1007/s10493-007-9053-6

Furtado IP (1997) Biossistemática e biologia de espécies de Euseius (Acari: Phytoseiidae) associadas à mandioca. Dissertation, Universidade de São Paulo

Furtado IP, de Moraes GJ, Kreiter S, Tixier M-S, Knapp M (2007) Potential of a Brazilian population of the predatory mite Phytoseiulus longipes as a biological control agent of Tetranychus evansi (Acari: Phytoseiidae, Tetranychidae). Biol Control 42:139-147. doi:10.1016/j.biocontrol.2007.04.016

Gasparich GE, Silva JG, Han HY, McPheron BA, Steck GJ, Sheppard WS (1997) Population genetic structure of Mediterranean fruit fly (Diptera: Tephritidae) and implications for worldwide colonization patterns. Ann Entomol Soc Am 90:790-797. doi:10.1093/aesa/90.6.790

Ghai S, Gupta SK (1984) A new species of Treatia Krantz and Khot (Acari: Otopheidomenidae) with a new record of Amblyseius berlese (Acari: Phytoseiidae) from India. Bull Zool Surv India 6:171-175

Gotoh T, Gutierrez J, Navajas M (1998) Molecular comparison of the sibling species Tetranychus pueraricola Ehara and Gotoh and T. urticae Koch (Acari: Tetranychidae). Entomol Sci 1:55-57

Haq MA (2001) Culture and rearing of Aceria guerreronis and its predators. Entomon 26:297-302 
Hillis DM, Dixon MT (1991) Ribosomal DNA: molecular evolution and phylogenetic inference. Q Rev Biol 66:411-453

Kanouh M, Tixier M-S, Guichou S, Kreiter S (2010a) Two synonymy cases within the genus Neoseiulella (Acari: Phytoseiidae): Is the molecular evidence so evident? Biol J Linn Soc 101:323-344. doi:10. 1111/j.1095-8312.2010.01516.x

Kanouh M, Tixier M-S, Okassa M, Kreiter S (2010b) Phylogenetic and biogeographic analysis of the genus Phytoseiulus (Acari: Phytoseiidae). Zool Scr 39:450-461. doi:10.1111/j.1463-6409.2010.00439.x

Lawson-Balagbo LM, Gondim MGC Jr, de Moraes GJ, Hana R, Schausberger P (2007) Refuge use by the coconut mite Aceria guerreronis: fine scale distribution and association with other mites under the perianth. Biol Control 43:102-110. doi:10.1016/j.biocontrol.2007.05.010

Lawson-Balagbo LM, Gondim MGC Jr, de Moraes GJ, Hana R, Schausberger P (2008) Exploration of the acarine fauna on coconut palm in Brazil with emphasis on Aceria guerreronis (Acari: Eriophyidae) and its natural enemies. Bull Entomol Res 98:83-96. doi:10.1017/S0007485307005421

Librado P, Rozas J (2009) DnaSP v5: a software for comprehensive analysis of DNA polymorphism data. Bioinformatics 25:1451-1452. doi:10.1093/bioinformatics/btp187

Lima DB, Melo JWS, Gondim MGC Jr, de Moraes GJ (2012) Limitations of Neoseiulus baraki and Proctolaelaps bickleyi as control agents of Aceria guerreronis. Exp Appl Acarol 56:233-246. doi:10. 1007/s10493-012-9515-3

Lindquist EE, Evans GO (1965) Taxonomic concept in the Ascidae, with a modified setal nomenclature for the idiosoma of the Gamasina (Acari: Mesostigmata). Mem Entomol Soc Can 47:1-64

Mayr E (1977) Populations, species, and evolution. Harvard University Press, Cambridge

Melo JWS, Lima DB, Staudacher H, Silva FR, Gondim MGC Jr, Sabelis MW (2015) Evidence of Amblyseius largoensis and Euseius alatus as biological control agent of Aceria guerreronis. Exp Appl Acarol 67:411-421. doi:10.1007/s10493-015-9963-7

Mendonça RS, Navia D, Diniz IR, Auger P, Navajas M (2011) A critical review on some closely related species of Tetranychus sensu stricto (Acari: Tetranychidae) in the public DNA sequences databases. Exp Appl Acarol 55:1-23. doi:10.1007/s10493-011-9453-5

Moore D, Howard FW (1996) Coconuts. In: Lindquist EE, Sabelis MW, Bruin J (eds) Eriophyoid mites: their biology, natural enemies and control. Elsevier, Amsterdam, pp 561-570

Nair CPR (2002) Status of eriophyid mite Aceria guerreronis Keifer in India. In: Fernando LCP, de Moraes GJ, Wickramananda IR (eds) Proceedings of the international workshop on coconut mite (Aceria guerreronis). Coconut Research Institute, Sri Lanka, pp 9-12

Navajas M, Fenton B (2000) The application of molecular markers in the study of diversity in Acarology: a review. Exp Appl Acarol 24:751-774. doi:10.1023/A:1006497906793

Navajas M, Gutierrez M, Langnel J (1996) Mitochondrial cytochrome oxidase I in tetranychid mites: a comparison between molecular phylogeny and change of morphological and life history traits. Bull Entomol Res 86:407-417. doi:10.1017/S0007485300034994

Navajas M, Langnel J, Gutierrez M, Boursot P (1998) Species wide homogeneity of nuclear ribosomal ITS2 sequences in the spider-mite Tetranychus urticae contrasts with extensive mitochondrial COI polymorphism. Heredity 87:742-752. doi:10.1046/j.1365-2540.1998.00349.x

Navajas M, Langnel J, Fauvel G, de Moraes GJ (1999) Sequence variation of ribosomal internal transcribed spacers (ITS) in commercially important Phytoseiidae mites. Exp Appl Acarol 23:851-859. doi:10. 1023/A:1006251220052

Navia D, Gondim MGC Jr, Aratchige NS, de Moraes GJ (2013) A review of the status of the coconut mite, Aceria guerreronis (Acari: Eriophyidae), a major tropical mite pest. Exp Appl Acarol 59:67-94. doi:10.1007/s10493-012-9634-x

Navia D, Domingos CA, Mendonça RS, Ferragut F, Rodrigues MAN, de Morais EGF, Tixier M-S, Gondim MGC Jr (2014) Reproductive compatibility and genetic and morphometric variability among populations of the predatory mite, Amblyseius largoensis (Acari: Phytoseiidae), from Indian Ocean Islands and the Americas. Biol Control 72:17-49. doi:10.1016/j.biocontrol.2014.01.011

Negloh K, Hanna R, Schausberger P (2008) Comparative demography and diet breadth of Brazilian and African populations of the predatory mite Neoseiulus baraki, a candidate for biological control of coconut mite. Biol Control 46:523-531. doi:10.1016/j.biocontrol.2008.04.022

Negloh K, Hanna R, Schausberger P (2010) Season- and fruit age-dependent population dynamics of Aceria guerreronis and its associated predatory mite Neoseiulus paspalivorus on coconut in Benin. Biol Control 54:349-358. doi:10.1016/j.biocontrol.2010.06.007

Noronha ACS, de Moraes GJ (2002) Variações morfológicas intra e interpopulacionais de Euseius citrifolius Denmark and Muma e Euseius concordis Chant (Acari: Phytoseiidae). Rev Bras Zool 19:1111-1122. doi:10.1590/S0101-81752002000400016 
Noronha ACS, de Moraes GJ (2004) Reproductive compatibility between mite populations previously identified as Euseius concordis (Acari: Phytoseiidae). Exp Appl Acarol 32:271-279. doi:10.1023/B: APPA.0000023238.18352.6c

Okassa M, Tixier M-S, Cheval B, Kreiter S (2009) Molecular and morphological evidence for new species status within the genus Euseius (Acari: Phytoseiidae). Can J Zool 87:689-698. doi:10.1139/Z09-057

Okassa M, Kreiter S, Guichou S, Tixier M-S (2011) Molecular and morphological boundaries of the predator Neoseiulus californicus McGregor (Acari: Phytoseiidae). Biol J Linn Soc 104:393-406. doi:10.1111/j.1095-8312.2011.01717.x

Ragusa S, Tsolakis H (1994) Revision of the genus Kampimodromus Nesbitt, 1951 (Parasitiformes, Phytoseiidae) with a description of a new species. Acarologia 35:305-322

Ramaraju K, Natarajan K, Babu PCS, Palnisamy S, Rabindra RJ (2002) Studies on coconut eriophyid mite, Aceria guerreronis Keifer in Tamil Nadu, Índia. In: Fernando LCP, de Moraes GJ, Wickramananda IR (eds) Proceedings of the international workshop on coconut mite (Aceria guerreronis). Coconut Research Institute, Sri Lanka, pp 13-31

Reis AC, Gondim MGC Jr, de Moraes GJ, Hanna R, Schausberger P, Schausberger P, Barros R (2008) Population dynamics of Aceria guerreronis Keifer (Acari: Eriophyidae) and associated predators on coconut fruits in northeastern Brazil. Neotrop Entomol 37:457-462. doi:10.1590/S1519566X2008000400015

SAS Institute (2002) SAS/STAT User's guide, version 8.02, TS level 2MO. SAS Institute Inc, Cary

Saunders DS (1982) Insect clocks. Pergamom Press, New York

Schicha E, Corpuz-Raros LA (1992) Phytoseiidae of the Philippines. Indira Publishing House, Michigan

Silva FR, Moraes GJ de, Sabelis MW, Hanna R, Estrada Venegas EG, Mesa NC, Vasquez C (2010) The search for natural enemies of the coconut mite (Aceria guerreronis Keifer) in Latin America. In: XIII international congress of acarology, Recife, pp 249-249

Skoracka A, Kuczynski L, Magowski W (2002) Morphological variation in different host populations of Abaracus hystrix (Acari: Prostigmata: Eriophyoidea). Exp Appl Acarol 26:187-193. doi:10.1023/A: 1021144729837

Thompson JD, Higgins DG, Gibson TJ (1994) Clustal-W improving the sensitivity of progressive multiple sequence alignment through sequence weighting, position-specific gap penalties and weight matrix choice. Nucleic Acids Res 22:4673-4680

Tixier M-S (2012) Statistical approaches for morphological continuous characters: a conceptual model applied to Phytoseiidae (Acari: Mesostigmata). Zool Scr 42:327-334. doi:10.1111/zsc.12004

Tixier M-S, Kreiter S, Barbar Z, Ragusa S, Cheval B (2006a) The status of two cryptic species: Typhlodromus exhilaratus Ragusa and Typhlodromus phialatus Athias-Henriot (Acari: Phytoseiidae): consequences for taxonomy. Zool Scr 35:115-122. doi:10.1111/j.1463-6409.2006.00222.x

Tixier M-S, Kreiter S, Ferragut F, Cheval B (2006b) The suspected synonymy of Kampimodromus hmiminai and Kampimodromus adrianae (Acari: Phytoseiidae): morphological and molecular investigations. Can J Zool 84:1216-1222. doi:10.1139/z06-108

Tixier M-S, Guichou S, Kreiter S (2008a) Morphological variation in the biological control agent Neoseiulus californicus (McGregor) (Acari: Phytoseiidae): consequences for diagnostic reliability and synonymies. Invert Syst 22:453-469. doi:10.1071/IS07052

Tixier M-S, Kreiter S, Croft BA, Cheval B (2008b) Kampimodromus aberrans (Acari: Phytoseiidae) from USA: morphological and molecular assessment of its density. Bull Entomol Res 98:125-134. doi:10. 1017/S0007485307005457

Tixier M-S, Ferrero M, Okassa M, Guichou S, Kreiter S (2010) On the specific identity of specimens of Phytoseiulus longipes Evans (Mesostigmata: Phytoseiidae) showing different feeding behaviours: morphological and molecular analyses. Bull Entomol Res 100:569-579. doi:10.1017/ S0007485309990617

Tixier M-S, Tsolakis H, Ragusa S, Poinso A, Ferrero M, Okassa M, Kreiter S (2011) Integrative taxonomy demonstrates the unexpected synonymy between two predatory mite species: Cydnodromus idaeus and C. picanus (Acari: Phytoseiidae). Invertebr Syst 25:273-281. doi:10.1071/IS11025

Tixier M-S, Okassa M, Kreiter S (2012) An integrative morphological and molecular diagnostics for Typhlodromus pyri (Acari: Phytoseiidae). Zool Scr 41:68-78. doi:10.1111/j.1463-6409.2011.00504.x

Tsolakis H, Tixier M-S, Kreiter S, Ragusa S (2012) The genus concept within the family Phytoseiidae (Acari: Parasitiformes). Historical review and phylogenetic analyses of the genus Neoseiulus Hughes. Zool J Linn Soc 165:253-273. doi:10.1111/j.1096-3642.2011.00809.x

Yaninek JS, Onzo A, Ojo JB (1993) Continent-wide releases of Neotropical phytoseiids against the exotic cassava green mite in Africa. Exp Appl Acarol 17:145-160. doi:10.1007/BF00156950 